\title{
The Influence of Personal Characteristics on Customers' Perception of E-Banking Service Quality and Cost Effectiveness in Vietnam
}

\author{
Ngo Mai Trang \\ Department of Psychology, VNU University of Social Sciences and Humanities, Vietnam National University, Hanoi, Vietnam \\ Email: trang_ngomai@yahoo.com
}

How to cite this paper: Trang, N. M. (2022). The Influence of Personal Characteristics on Customers' Perception of E-Banking Service Quality and Cost Effectiveness in Vietnam. Open Journal of Social Sciences, 10, 377-391. https://doi.org/10.4236/jss.2022.101029

Received: December 2, 2021

Accepted: January 24, 2022

Published: January 27, 2022

Copyright $\odot 2022$ by author(s) and Scientific Research Publishing Inc. This work is licensed under the Creative Commons Attribution International License (CC BY 4.0).

http://creativecommons.org/licenses/by/4.0/

\begin{abstract}
An extensive literature review found that customer's perception of service quality and cost effectiveness are the most important factors for the success or failure of service providers. There is evidence of the relation between a number of demographic factors and perception of service quality. The data was collected through the survey of E-Banking customers $(\mathrm{N}=754)$ in four major cities and towns and the countryside in Vietnam. Perception of service quality and cost effectiveness is measured by the following dimensions: reliability, security, convenience, ease of use, customer support and cost effectiveness. The results from the study revealed significant differences in perception of service quality and cost effectiveness by gender, occupation, living place and experience of using E-Banking, while no significant difference was found for education, income, age and variety seeking factors. The results of the study enhance the understanding of perception of service quality and cost effectiveness in Vietnam E-Banking area and provide useful knowledge in the management and delivery of service quality.
\end{abstract}

\section{Keywords}

Perception of Service Quality, Cost Effectiveness, E-Banking, Personal Characteristics

\section{Introduction}

Since electronic banking service appeared in Vietnam in 2002, the number of banks providing and customers using this service has been increasing rapidly. In 2015, most commercial banks provided internet banking services. According to a survey of global consumption by $\mathrm{PwC}$ in 2019 in 27 countries and territories 
(PwC, 2019), Vietnam was expected to become the fastest-growing market for e-payment via Internet in the area. Statistics showed that the percentage of customers paying via mobile in Vietnam has grown quickly year by year, from $37 \%$ in 2018 to about $62 \%$ in 2019 . This growth rate was recorded as the highest among the 6 Southeast Asian countries, including Malaysia, the Philippines, and Thailand. The banking sector, the backbone of the Vietnamese economy, has been witnessing unprecedented growth, especially with regard to electronic services (PwC, 2019). Vietnamese banks are using advancements in their E-Banking services for retaining and attracting clients, therefore they have made big investments in implementing the latest E-Banking technology to improve their competitiveness.

Customer perception of service quality is considered to directly influence their satisfaction and to be the most important factor to the success or failure of a service (Hennig-Thurau \& Klee, 1997). Quality of products and services has been proved to increase financial performance and profitability (Zeithaml, Berry, \& Parasuraman, 1996). As a result, providing high-quality products and services to customers has become a primary goal for many companies. According to Homburg and Giering (2001), personal characteristics of customers such as variety seeking and demographic characteristics are useful in explaining future consumption behaviour. According to Kotler \& Armstrong (2010), demographic characteristics are acceptable bases for segmenting customers and markets. Socio-demographic characteristics such as gender, age, income, marital status, education, and occupation have long been identified as having significant relation with the perception of service quality (Sein \& Chey, 2013). According to Lucyna (2016), socio-demographic characteristics are the most popular and well-accepted bases for market segmentation and customers profiling. Service quality is perceived differently by consumers according to their socio-demographic background. However, the relation between customers' personal characteristics and perception of quality in the context of E-Banking services remain unexplored. In general, studies on perception of E-Banking service quality rarely mentioned certain issues of urban/rural areas, customers' experience and variety seeking.

Thus the objective of this study is to provide additional understanding of customers' perception of service quality of E-Banking and clarify its relation with personal characteristics of customers.

\section{Literature Review}

\subsection{Perception of Service Quality and Cost Effectiveness}

Perception of service quality is a customer's psychological reaction to the quality of a service that a company provides. Zeithaml (1988) defined perceived service quality as a consumer's judgment about an entity's overall excellence or superiority. Besides perceived service quality is regarded as "a focus evaluation that reflects the customer perception of specific dimensions of service" (Zeithaml \& 
Bitner, 2000). According to Santos (2003), service quality is one of the main factors determining the success and failure of electronic commerce that E-Banking is a part of. For banks, the ultimate goal of implementing E-Banking is to reach more customers or to get more market share. But they may create barriers by themselves preventing customers from approaching E-Banking. They may be complicated procedures, inflexible regulations, or high service costs. Those barriers discourage customers to utilise E-Banking. The first service quality models emerged in 1980's in researches by Grönroos (1984) and Parasuraman et al. (1985, 1988). Grönroos (1984) suggested two service quality dimensions-functional quality and technical quality. Technical quality is what the consumers receive as a result of interaction with a service provider, while functional quality is concerned with how consumers receive services (Grönroos, 1988). According to the American model SERVQUAL, service quality is the difference between the expected level of service and customer perceptions of the level received (Parasuraman et al., 1985). The SERVQUAL model mainly describes how the quality of the website along with its services will affect users' perception and satisfaction with E-Banking. The core dimensions of this model are: Empathy, Reliability, Responsiveness, Assurance, and Tangibility. Service quality can be assessed by various measurement tools and instruments developed by various researchers and marketing consultancy organisations, for example, Gronroos's Perceived Service Quality Model, SERVQUAL, E-S-QUAL, SERVPERF, SITQUAL, WEBQUAL, etc. Prior studies identified some of the key dimensions of E-Banking service quality as responsiveness, reliability, security and privacy (Parasuraman et al., 1985, 1988), ease of use (Sathye, 1999; Yoo \& Donthu, 2001; Kwon \& Chidambaram, 2000), convenience (Joseph et al., 1999; Ankit, 2011), cost effectiveness (Ankit, 2011).

Lustsik (2004) defines E-Banking services as a variety of e-channels for doing banking transactions through Internet, telephone, TV, mobile, and computer. E-Banking is the access of the customers to bank services by secure intermediaries without any physical presence (Daniel, 1999). The main difference of E-Banking from traditional banking is the focus on providing convenience to customers. Lichtenstein \& Williamson (2006) stated that it provides customers convenience and flexibility and can be provided at a lower cost than traditional branch banking. The study suggested that convenience, reliability and security, customer support, easy to use are four important dimensions of perception of E-Banking service quality.

Reliability is defined as the service provider performs the services right the first time and the firm honors its promises (Tran, 2018; Van \& Lee, 2012). It involves in accuracy in billing, keeping records correctly, performing the service at the designated time.

Service Security is defined as the customers' possession and personal safety. It includes confidentiality maintained by service providers, making customers feel safe in their transactions (Parasuraman et al., 1985). 
According to Supinaha et al. (2008), convenience is considered to be one of the most influential factors to the delivery of E-Banks services to customers. E -banking transactions are done quickly, with conveniences such as wire/card transfer, 24/7 service time...Supinaha et al. (2008), Poon (2008) and Hazlina et al. (2011) found that electronic banking provides a higher degree of convenience that enables customers to access bank services at all times around the globe.

Customer support includes pre-sale support and after-sale support. In using E-Banking services, customers need assistance to solve the problem that they encounter or may have questions or instructions on how to use the services.

Easy to use relates to ease of access to the E-Banking website, ease of use of services, the website has easy-to-understand content, terms and conditions (Sathye, 1999).

Cost effectiveness is one of the major factors in attracting consumers to use E-Banking services. Prior researches has found cost/fees effectiveness have a positive relationship with customer service satisfactory and as a critical factor to the use of electronic banking (Cheah et al., 2011). According to Drucker (1985), electronic banking is the answer to cost/fees reduction, sustainability and reaching the very poor. Transaction fees have two categories, the first is regular costs relating to internet access fees and connection payment and the second is the bank fees and charges. There are also promotional offers on products such as credit cards and loans (Hawkins, 2012). The role of costs/fees has been assessed by reasonable cost of electronic banking and lower transaction fees. According to Ming (2003) the level of e-satisfaction is also determined by the quality of e-services, the price level and e-purchasing process.

\subsection{The Relation of Personal Characteristics and the Perception of E-Banking Service Quality and Cost Effectiveness}

Based on researches on factors involving consumer purchasing behaviours, six demographics and two psychological factors were chosen to examine their relation with the perception of customers. Such factors have been found to be related to consumer perception and behaviours.

Gender: Previous research on the relation between gender and customer perception of service quality has produced somewhat conflicting results. For example, Homburg \& Giering (2001) found that, female customers tend to rate service quality lower when comparisons were made for both sexes. Hennig-Thurau et al. (2010) suggests service quality may be more important to women than to men when transacting business with bank. Hung (2006), Okeke \& Okpala (2014) found that male customers have a more positive perception of the quality of service they receive than female customers. Tolpa (2012) found no differences in the perception of service quality based on gender.

Age: Homburg \& Giering (2001) suggests older consumers are not encouraged to use E-Banking due to limitation in movement and vision. Times (1996) showed that the Internet users tend to be for young adult and they would be very much attracted to innovative banking services. The mid-aged people are more 
likely to use Internet banking than younger or older consumers and they will have an important effect on subsequent adoption of further new technology (Akinci et al., 2004; Laforet \& Li, 2005). Spacey et al. (2004) showed that older people are less convenient when using technology.

Education level: People with higher educational level may have competence for computers and possess good information processing skills, which better facilitate Internet use (Nasri, 2011). Izogo et al. (2012) found that more educated consumers adopt E-Banking than the less educated ones.

Occupations: some research has found that occupation is a significant factor related to customer's perceptions of service quality. Aga \& Safakli (2007) found that service quality perceptions differ across customers of different occupational groups. People buy products and services that match with requirements of occupations they pursue. Knowledge of customer's occupation can help marketers in devising strategies capable of delivering services more effectively to respond to the specific needs of customers belonging to different occupational groups (Lal et al., 2014).

Income: Zeithaml (1988) suggested that consumption decisions are largely influenced by income because higher incomes allow consumers to have more choices. Meng and Altobello (2009) found that Chinese consumers shop at different stores based on their income level. Kotler \& Armstrong (2010) suggested an increase in educated people, or high income people, leads to an increase in the demand for quality products. Thus, customers with higher income levels may perceive service quality differently from their lower income counterparts.

Living place: Consumption convenience refers to the points of interaction between banks and customers such as distance to bank branches, ATM locations, Internet availability. Therefore, customers in different geographical areas have different services access and consumption behaviors (Lambert-Pandraud et al., 2005; Jeong, 2013). Tran Duc Thang (Tran, 2015) found that customers using E-Banking services mainly live in big cities in Vietnam.

Experience in using E-Banking: Customer experience is particularly important in banking because customers have such a wide range of options to choose from and they are also careful about their choices. Customer experience is influenced by time spent on the Internet, frequency of visits to Websites and transaction success. O'Cass and Fenech (2003) indicated that accumulated sufficient Internet experience creates a belief in Internet users' ability to use the Internet for commercial purposes. According to Polasik and Wisniewski (2008), Internet familiarity/experience is an important factor that influences customers to adopt Internet banking. Karjaluoto et al. (2002) found prior computer experience, prior technology experience \& prior personal banking experience positively affect consumer's attitude and behavior towards online banking.

Variety Seeking is a topic that psychologists and consumer behaviorists have studied extensively. Variety seeking has a negative moderator effect on the relationship between satisfaction with the product and loyalty (Homburg \& Giering, 2001). Therefore, it is considered a phenomenon related to products and servic- 
es. Variety seeking is viewed as a phenomenon that derives from internal motivation and external stimuli. Variety seeking is a cognitive commitment to buying different brands because of factors such as the stimulation involved in trying various brands, curiosity about something new, or something new can help overcome boredom with the same old thing (Peter \& Olson, 2010). According to Mowen and Minor (1997) variety seeking or seeking diversity refers to the tendency of consumers to seek and buy new products and services even though they keep expressing satisfaction with the old brand (Blattberg \& Neslin, 1990).

\section{Methodology}

The research has been conducted in two major cities, and towns and countryside in two provinces in Vietnam (Hanoi, Ho chi Minh city, Quang ninh và Khanh Hoa provinces). The targets are banking customers who have active bank accounts in various public, private and foreign banks in Vietnam and are using e -banking services. A total of 780 customers from 8 different banks have been approached, among them 754 properly completed the self-report questionnaires. The data was collected in four months (from Jul to Oct 2020). The questionaires include items to collect information of demographics and personal characteristics, and perception of E-Banking service quality and cost effectiveness. In this study, the perception of E-Banking service quality and cost effectiveness was measured in five dimensions: reliability and security, convenience, ease of use, customer support and cost effectiveness, which was designed based on the original SERVQUAL scale. These dimensions and the items were chosen from previous studies that measured the e-service quality of internet banking in Vietnam. The questionaire consists of 23 likert-5-point-scale items ranging from 1 strongly disagree to 5 strongly agree. The questionnaire was pre-tested in 150 E-Banking consumers. Based on their feedback, the questionnaire was revised to improve its clarity, relevance, and comprehensibility. The score of each dimension is the mean of the corresponding items scores. One-Way ANOVA and Independent-Samples $\mathrm{T}$ test were used to perform mean comparison in order to determine if there are differences in perception of service quality resulting from customer's personal characteristics. The variables that were considered in this study were gender, occupation, living place, experience in using E-Banking, age, educational qualification, income and variety seeking. The primary data were analyzed by SPSS version 25.0.

Eight hypotheses regarding personal characteristics effect on service perception were developed:

H1: The perceptions of service quality and cost effectiveness differ among gender groups of E-Banking customers.

Independent-Samples $\mathrm{T}$ tests were utilized to examine statistically significant difference between male and female group means.

$\mathrm{H} 2$ : The perceptions of service quality and cost effectiveness differ among occupational groups of E-Banking customers. 
One-Way ANOVA was utilized to examine statistically significant difference among different occupational group means.

H3: The perceptions of service quality and cost effectiveness differ among E-Banking customers by living place factor.

Independent-Samples $\mathrm{T}$ tests were utilized to examine statistically significant difference between city and town/countryside group means.

H4: The perceptions of service quality and cost effectiveness differ among E-Banking customers by experience in using E-Banking factor.

Independent-Samples $\mathrm{T}$ tests were utilized to examine statistically significant difference between two group means, the first group consists of customers having less than two years of experience in using E-Banking, the other consists of customers having two years of experience and above.

H5: The perceptions of service quality and cost effectiveness do not differ among educational qualification groups of E-Banking customers.

One-Way ANOVA was utilized to examine statistically significant difference among different educational qualification group means.

H6: The perceptions of service quality and cost effectiveness do not differ among income groups of E-Banking customers.

One-Way ANOVA was utilized to examine statistically significant difference among different income group means.

H7: The perceptions of service quality and cost effectiveness do not differ among age groups of E-Banking customers.

One-Way ANOVA was utilized to examine statistically significant difference among different age group means.

H8: The perceptions of service quality and cost effectiveness do not differ among E-Banking customers by variety seeking factor as the number of E-Banking providers.

One-Way ANOVA was utilized to examine statistically significant difference among different group means in terms of variety seeking factor.

\section{Results of Hypotheses Testing and Discussion}

Demographic profile of the respondents was presented in Table 1. Variety seeking was regarded as the number of E-Banking providers/banks that respondents utilized at that time. Experience in using E-Banking was measured by the number of years customers have been using the service. The difference in the number of E-Banking customers across living places can be explained by the availability of bank branches which locate mainly in cities.

\subsection{Perception of Service Quality and Cost Effectiveness}

Cronbach's Alpha Test of Reliability was utilized for the reliability test. According to Nunnally (1978) Cronbach's alpha should be 0.70 or above. Perception of service quality and cost effectiveness was measured by 23 items with high reliability (0.87), comprising of 5 dimentions: convenience, reliability and security, 
Table 1. Demographic profile of the respondents.

\begin{tabular}{|c|c|c|c|c|c|}
\hline & $\mathbf{n}$ & $\%$ & & $\mathbf{n}$ & $\%$ \\
\hline \multicolumn{3}{|l|}{ Age } & \multicolumn{3}{|l|}{ Experience in using E-Banking by years } \\
\hline Under 30 years old & 271 & 36 & Less than 2 years & 240 & 31.8 \\
\hline From 31 to 45 years old & 321 & 42.5 & $2-4$ years & 420 & 55.7 \\
\hline From 45 to 60 years old & 162 & 21.5 & 5 years or more & 94 & 12.5 \\
\hline Living place & \multicolumn{5}{|c|}{ Gender } \\
\hline Cities & 466 & 61.8 & Female & 453 & 60 \\
\hline Towns and countryside & 288 & 38.2 & Male & 301 & 40 \\
\hline Education & & & \multicolumn{3}{|l|}{ Occupation } \\
\hline High school & 131 & 17.4 & Students & 176 & 23.3 \\
\hline Vocational/intermediate school & 99 & 13.1 & Office employee, public officials & 244 & 32.4 \\
\hline Graduate University & 383 & 50.8 & Self-business & 96 & 12.7 \\
\hline Master/PhD & 141 & 18.7 & Others (workers, farmers, pensioners, house-wives...) & 238 & 31.6 \\
\hline \multicolumn{3}{|l|}{ Income/month } & \multicolumn{3}{|l|}{ Number of current E-Banking providers } \\
\hline Under 5 million & 193 & 25.6 & One & 531 & 70.4 \\
\hline From 5 to less than 10 million VND & 193 & 25.6 & Two & 149 & 19.8 \\
\hline From 10 to less than 15 million VND & 159 & 21.1 & Three and above & 74 & 9.8 \\
\hline From 15 to under 20 million VND & 91 & 12.1 & & & \\
\hline Over 20 million & 118 & 15.6 & & & \\
\hline $\mathrm{N}=754$ & & & & & \\
\hline
\end{tabular}

customer support, ease of use and cost effectiveness. The response ranged from 1-the lowest to 5-the highest. The points awarded are as follows: Very Poor $=0$ 0.99; Poor $=1-1.99$; Average $=2-2.99$; Above average $=3-3.99$; Good $=4-5$. Customer's overall perception of E-Banking service quality and cost effectiveness was 4.14 , indicating that customers in general evaluate the quality of banking services and cost effectiveness as good. The mean of each item ranged from 3.62 to 4.46 , while the standard deviation ranged from 0.65 to 1.03 . Cost effectiveness received the lowest score, 3.17, compared to other dimensions, which was also the only dimension rated as above average. See Table 2.

\subsection{Results of Hypothesis Testing}

$\mathrm{H} 1, \mathrm{H} 2, \mathrm{H} 3$ and $\mathrm{H} 4$, examining the effect of E-Banking customer's gender, occupation, living place, experience on perception of service quality and cost effectiveness, were supported (see Table 3). The t-test results suggested significant differences exist between woman and man, i.e. male perceived service quality and cost effectiveness higher than female $(t=5.743, p<0.01)$. ANOVA indicates a statistically significant difference among occupational group means, perception of service quality and cost effectiveness is significantly related to occupation (Welch $=2.948, p<0.01$ ). The mean score for self-business is slightly higher than other occupational groups however, the mean score for the other occupa- 
tional categories did not significantly differ. A significant difference was found in the mean comparison for customer's living place $(t=5.868, p<0.01)$. Customers living in cities perceived service quality and cost effectiveness higher than those in towns and countryside. Similarly, perception of service quality and cost effectiveness was affected by experience in E-Banking, i.e. customers of less than 2 years of experience had lower perception $(t=4.090, p<0.01)$.

Table 2. Mean score of perceived service quality and cost effectiveness.

\begin{tabular}{|c|c|c|c|}
\hline Perceived service quality and cost effectiveness & Mean & Std. deviation & Cronbach Alpha \\
\hline 1. Convenience & 4.36 & 0.58 & 0.821 \\
\hline Transactions are accomplished quickly & 4.35 & 0.73 & \\
\hline There are several payment services (utilities, mobile charges...) & 4.37 & 0.71 & \\
\hline There are several methods for money transfer (normal/quick, account/card transfer...) & 4.46 & 0.65 & \\
\hline Service time of $24 / 7$ & 4.33 & 0.8 & \\
\hline $\begin{array}{l}\text { E-Banking network is convenient (ATM, many apps/web/e-wallet allow E-Banking } \\
\text { transactions...) }\end{array}$ & 4.26 & 0.86 & \\
\hline 2. Reliability and security & 4.15 & 0.68 & 0.853 \\
\hline Personal information is kept confidential & 4.16 & 0.82 & \\
\hline Information about account balances, transactions are confidential & 4.19 & 0.78 & \\
\hline Personal information is not misused by the banks & 4.11 & 0.83 & \\
\hline No risk when using money transfer services via E-Banking & 4.14 & 0.82 & \\
\hline No risk when using payment services via E-Banking & 4.13 & 0.83 & \\
\hline 3. Customer support & 4.1 & 0.7 & 0.898 \\
\hline Bank staff are open and friendly & 4.10 & 0.8 & \\
\hline Bank staff answer questions clearly and accurately & 4.11 & 0.75 & \\
\hline Bank staff assist in handling the problem until the problem is resolved & 4.10 & 0.76 & \\
\hline 4. Ease of use & 4.38 & 0.6 & 0.802 \\
\hline Able to use E-Banking services by several means (phones, ATMs, computers...) & 4.36 & 0.75 & \\
\hline Easy to use money transfer services & 4.40 & 0.69 & \\
\hline Easy to use bill payment services & 4.39 & 0.66 & \\
\hline Easy to view statement balance via E-Banking & 4.40 & 0.72 & \\
\hline Easy to access to E-Banking accounts & 4.34 & 0.7 & \\
\hline 5. Cost effectiveness & 3.71 & 0.87 & 0.781 \\
\hline The annual/monthly fee of the bank card is reasonable & 3.63 & 1.02 & \\
\hline E-Banking service maintenance fee is reasonable & 3.69 & 1.03 & \\
\hline Money transfer fee through E-Banking account is reasonable & 3.70 & 1.05 & \\
\hline Payment fee through bank account/card is reasonable & 3.62 & 1.01 & \\
\hline The bank regularly waive/reduce E-Banking services & 3.88 & 1.00 & \\
\hline Perception of service quality and cost effectiveness & 4.14 & 0.49 & 0.87 \\
\hline
\end{tabular}


H5, H6, H7 and H8, examining the effect of customer's education, income, age and variety seeking on perception of service quality and cost effectiveness, were not supported (see Table 4). The result of ANOVA test shows that educational qualification did not cause any significant difference in the means of perception of service quality and cost effectiveness (Welch $=0.653, p>0.05$ ). No significant difference was found in the mean comparison for incomes (Welch $=$ 1.688, $p>0.05)$. Similarly, the age of customers did not lead to any significant difference in the means of perception of service quality and cost effectiveness (Welch $=0.001, p>0.05)$. The variety seeking factor did not cause significant difference in the means of perception of service quality and cost effectiveness (Welch $=0.003, p>0.05)$. This implies that customer's perception of service quality and cost effectiveness is not influenced by education, income, age and variety seeking factor.

Table 3. Mean difference in perceptions of E-Banking service quality and cost effectiveness by gender, living place, years of experience and occupation.

\begin{tabular}{|c|c|c|c|c|c|}
\hline & $\mathbf{n}$ & Mean & S.D. & F & $\mathbf{t}$ \\
\hline \multicolumn{6}{|l|}{ 1. Gender } \\
\hline Male & 301 & 4.258 & 0.400 & 18.559 & $5.743^{* *}$ \\
\hline Femal & 453 & 4.062 & 0.536 & & \\
\hline \multicolumn{6}{|l|}{ 2. Living place } \\
\hline Cities & 466 & 4.22 & 0.44 & 5.868 & $5.769^{* *}$ \\
\hline Towns and countryside & 288 & 4.00 & 0.55 & & \\
\hline \multicolumn{6}{|l|}{ 3. Years of experience } \\
\hline Less than 2 years & 240 & 4.019 & 0.554 & 4.090 & $-4.338^{\star *}$ \\
\hline \multirow[t]{2}{*}{2 years and above } & 514 & 4.197 & 0.455 & & \\
\hline & $\mathbf{n}$ & Mean & S.D. & Welch & \\
\hline \multicolumn{6}{|l|}{ 4. Occupation } \\
\hline Students & 176 & 4.126 & 0.477 & $2.948^{* *}$ & \\
\hline Office workers, publuc officials & 244 & 4.129 & 0.458 & & \\
\hline Self-business & 96 & 4.274 & 0.470 & & \\
\hline $\begin{array}{c}\text { Others (workers, farmers, pensioners, } \\
\text { house-wives...) }\end{array}$ & 238 & 4.108 & 0.547 & & \\
\hline
\end{tabular}

Table 4. Mean difference in perceptions of E-Banking service quality and cost effectiveness by education, incomes, age and variety seeking factor.

\begin{tabular}{ccccc}
\hline & $\mathbf{n}$ & Mean & S.D. & Welch \\
\hline Level of education & & & & \\
\hline High school & 131 & 4.178 & 0.439 & 0.653 \\
Vocational/intermediate school & 99 & 4.116 & 0.465 & \\
\hline
\end{tabular}




\section{Continued}

\begin{tabular}{ccccc}
\hline University & 383 & 4.147 & 0.531 & \\
Master/PhD & 141 & 4.101 & 0.463 & \\
\hline Incomes & & & & \\
\hline Under 5 million & 193 & 4.125 & 0.475 & 1.688 \\
From 5 to less than 10 million VND & 193 & 4.187 & 0.474 & \\
From 10 to less than 15 million VND & 159 & 4.145 & 0.413 & \\
From 15 to under 20 million VND & 91 & 4.184 & 0.503 & \\
Over 20 million & 118 & 4.048 & 0.631 & \\
Age & & & & \\
\hline Under 30 years old & 271 & 4.139 & 0.465 & 0.001 \\
From 31 to 45 years old & 321 & 4.140 & 0.522 & \\
Over 45 years old & 162 & 4.141 & 0.491 & \\
\hline Number of current E-Banking providers & & & & \\
\hline One $p<05, * * p<0.01, \mathrm{n}=754$. & 531 & 4.162 & 0.625 & 0.003 \\
Two & 149 & 4.128 & 0.512 & \\
\hline Three and above & 74 & 4.13 & 0.641 & \\
\hline & & & & \\
\hline
\end{tabular}

\section{Discussion and Conclusion}

Previous studies have largely ignored the impact of personal characteristics on the perception of E-Banking service quality and cost effectiveness. In this study, the influence of individual characteristics on perceived E-Banking service quality and cost effectiveness was analyzed. Research results have found a significant difference among customer groups regarding the perception of E-Banking service quality and cost effectiveness. Specifically, gender, occupation, living place and experience are considered important factors affecting the perception of E-Banking service quality and cost effectiveness. No evidence was found for the impact of education, income, age and variety seeking on perception of service quality and cost effectiveness.

Therefore, this study contributes significantly to a better understanding of the influence of personal characteristics on customers' perceptions of service quality and cost effectiveness in the context of emerging E-Banking services in Vietnam recently. Previous researches have shown that customer demographic variables have little or no influence on the perception of banking service quality. However, this study shows that customers' gender, occupation, living place and experience in using E-Banking are related to their perception of E-Banking service quality. Besides demographic characteristics, the study has mentioned the impact of individual characteristics such as experience in using E-Banking and variety seeking. Many researchers have shown that the main benefit of including demographics in researches of consumer behavior management is that in many situa- 
tions, the demographic characteristics of customers reflect their psychological states, values, and behaviors (e.g. Kalyanam \& Putler, 1997; Reinartz \& Kumar, 2000).

The results provide managers with detailed understanding of perception of E-Banking service quality and cost effectiveness in different consumer groups. As perception of quality services has a positive relation with satisfaction and loyalty, these findings can be used for the purposes of effective resource allocation in customer satisfaction and retention programs. For example, the findings show that it is very important to focus on the satisfaction of male customers and young self-businesses in the service delivery process.

\section{Limitations and Future Research}

The study did not fully indicate the personal characteristics, for example, marital status, ethnicity, attitude and personality were not included. The inclusion of a full range of personal characteristic variables can bring insights into factors that influence perception of service quality and cost effectiveness. Furthermore, interaction effects in personal variables were not investigated, which could be examined in future researches.

\section{Conflicts of Interest}

The author declares no conflicts of interest regarding the publication of this paper.

\section{References}

Aga, M., \& Safakli, O. (2007). An Empirical Investigation of Service Quality and Customer Satisfaction in Professional Accounting Firms: Evidence from North Cyprus. Problems and Perspectives in Management, 5, 84-98.

Akinci, S., Aksoy, S., \& Atilgan, E. (2004). Adoption of Internet Banking among Sophisticated Consumer Segments in an Advanced Developing Country. International Journal of Bank Marketing, 22, 212-232. https://doi.org/10.1108/02652320410530322

Ankit, S. (2011). Factors Influencing Online Banking Customer Satisfaction and Their Importance in Improving Overall Retention Levels: An Indian Banking Perspective. Information and Knowledge Management, 1, 45-55.

Blattberg, R. C., \& Neslin, S. A. (1990). Sales Promotion: The Long and the Short of It. Marketing Letters, 1, 81-97. https://doi.org/10.1007/BF00436151

Cheah, C. M., Teo, A., Sim, J. J., Kam, H., Oon, K. H., \& Tan, B. (2011). Factors Affecting Malaysian Mobile Banking Adoption: An Empirical Analysis. International Journal of Network and Mobile Technologies, 2, 149-160.

Clemes, M. D., Gan, C., Kao, T. H., \& Choong, M. (2008). An Empirical Analysis of Customer Satisfaction in International Air Travel. Innovative Marketing, 4, 49-62.

Daniel, E. (1999). Provision of Electronic Banking in the UK and the Republic of Ireland. International Journal of Bank Marketing, 17, 72-83. https://doi.org/10.1108/02652329910258934

Drucker, P. F. (1985). Innovation and Entrepreneurship: Practice and Principles. University of Illinois at Urbana-Champaign's Academy for Entrepreneurial Leadership His- 
torical Research Reference in Entrepreneurship.

Grönroos, C. (1984). A Service Quality Model and its Marketing Implications. European Journal of Marketing, 18, 36-44. https://doi.org/10.1108/EUM0000000004784

Grönroos, C. (1988). Service Quality: The Six Criteria of Good Perceived Service Quality. Review of Business, 9, 10-13.

Han, H., \& Jeong, C. (2013). Multi-Dimensions of Patrons' Emotional Experiences in Upscale Restaurants and Their Role in Loyalty Formation: Emotion Scale Improvement. International Journal of Hospitality Management, 32, 59-70.

https://doi.org/10.1016/j.ijhm.2012.04.004

Hawkins, P. (2012). Can Agency Banking Improve Financial Inclusion in South Africa? FinMark Trust.

Hazlina, T. et al. (2011). Impacts of Service Quality on Customer Satisfaction: Study of Online Banking and ATM Services in Malaysia. International Journal of Trade, Economics and Finance, 2, 10-23.

Hennig-Thurau, T., \& Klee, A. (1997). The Impact of Customer Satisfaction and Relationship Quality on Customer Retention: A Critical Reassessment and Model Development. Psychology \& Marketing, 14, 737-764. https://doi.org/10.1002/(SICI)1520-6793(199712)14:8\%3C737::AID-MAR2\%3E3.0.CO;2-F

Hennig-Thurau, T., Malthouse, E. C., Friege, C., Gensler, S., Lobschat, L., Rangaswamy, A., \& Skiera, B. (2010). The Impact of New Media on Customer Relationships. Journal of Service Research, 13, 311-330. https://doi.org/10.1177/1094670510375460

Homburg, C., \& Giering, A. (2001). Personal Characteristics as Moderators of the Relationship between Customer Satisfaction and Loyalty-An Empirical Analysis. Psychology \& Marketing, 18, 43-66. https://doi.org/10.1002/1520-6793(200101)18:1\%3C43::AID-MAR3\%3E3.0.CO;2-I

Hung, P. S. (2006). Continued Use of a Chinese Online Portal: An Empirical Study. Behaviour \& Information Technology, 27, 201-209. https://doi.org/10.1080/01449290600802403

Izogo, E. et al. (2012). Impact of Demographic Variables on Consumers' Adoption of E-Banking in Nigeria: An Empirical Investigation. European Journal of Business and Management, 4, 27-39.

Jeong, C. (2013). Multi-Dimensions of Patrons' Emotional Experiences in Upscale Restaurants and Their Role in Loyalty Formation: Emotion Scale Improvement. International Journal of Hospitality Management, 32, 59-70.

https://doi.org/10.1016/j.ijhm.2012.04.004

Joseph, M., McClure, C., \& Joseph, B. (1999). Service Quality in the Banking Sector: The Impact of Technology on Service Delivery. International Journal of Bank Marketing, 17, 182-193. https://doi.org/10.1108/02652329910278879

Kalyanam K., \& Putler, D. S. (1997). Incorporating Demographic Variables in Brand Choice Models: An Indivisible Alternatives Framework. Marketing Science, 16, 97-181. https://doi.org/10.1287/mksc.16.2.166

Karjaluoto, H., Mattila, M., \& Pento, T. (2002). Electronic Banking in Fin-Land: Consumer Beliefs and Reactions to a New Delivery Channel. Journal of Financial Services Marketing, 6, 346-361. https://doi.org/10.1057/palgrave.fsm.4770064

Kotler, P., \& Armstrong, G. (2010). Principles of Marketing. Prentice Hall.

Kwon, H. S., \& Chidambaram, L. (2000). A Test of the Technology Acceptance Model: The Case of Cellular Telephone Adoption. In Proceedings of the 33rd Annual Hawaii International Conference on System Sciences (pp. 7). IEEE. 
https://doi.org/10.1109/HICSS.2000.926607

Laforet, S., \& Li, X. (2005). Consumers' Attitudes towards Online and Mobile Banking in China. International Journal of Bank Marketing, 23, 362-380. https://doi.org/10.1108/02652320510629250

Lal, J., Vij, M., \& Jain, S. (2014). Do Demographics Influence Customer Service Quality Perceptions? A Comparative Study of Indian and Foreign Banks. Journal of Services Research, 14, 75-105.

Lambert-Pandraud, R., Laurent, G., \& Lapersonne, E. (2005). Repeat Purchasing of New Automobiles by Older Consumers: Empirical Evidence and Interpretations. Journal of Marketing, 69, 97-113. https://doi.org/10.1509/jmkg.69.2.97.60757

Lichtenstein, S., \& Williamson, K. (2006). Understanding Consumer Adoption of Internet Banking: An Interpretive Study in the Australian Banking Context. Journal of Electronic Commerce Research, 7, 50-66.

Lucyna, W. (2016). Influence of Socio-Demographic Characteristics of Consumers on Attitudes towards Cause Related Marketing. Acta Universitatis Agriculturae et Silviculturae Mendelianae Brunensis, 64, 2173-2182.

https://doi.org/10.11118/actaun201664062173

Lustsik, O. (2004). Can E-Banking Services Be Profitable? University of Tartu Economics and Business Administration, Working Paper No. 30-2004.

https://doi.org/10.2139/ssrn.612762

Meng, J., \& Altobello Nasco, S. (2009). Cross-Cultural Equivalence of Price Perceptions across American, Chinese, and Japanese Consumers. Journal of Product \& Brand Management, 18, 506-516. https://doi.org/10.1108/10610420910998235

Ming, W. (2003). Assessment of E-Service Quality via E-Satisfaction in E-Commerce Glo-Balization. The Electronic Journal on Information System in Developing Countries (EJISDC), 11, 1-4. https://doi.org/10.1002/j.1681-4835.2003.tb00073.x

Mowen, J., \& Minor, M. (1997). Consumer Behaviour. Prentice-Hall, Inc.

Nasri, W. (2011). Factors Influencing the Adoption of Internet Banking in Tunisia. International Journal of Business and Management, 6, 143-160.

Nunnally, J. (1978). Psychometric Theory. McGraw-Hill.

O'Cass, A., \& Fenech, T. (2003). Web Retailing Adoption: Exploring the Nature of Internet Users Web Retailing Behaviour. Journal of Retailing and Consumer Services, 10, 81-94. https://doi.org/10.1016/S0969-6989(02)00004-8

Okeke, T. C., \& Okpala, C. G. (2014). A Discrete Analysis of Demography and Electronic Banking Usage in Nigeria. Journal of Internet Banking and Commerce, 19, 1-14.

Parasuraman, A., Zeithaml, V. A., \& Berry, L. L. (1985). A Conceptual Model of Service Quality and Its Implications for Future Research. Journal of Marketing, 49, 41-50. https://doi.org/10.1177/002224298504900403

Parasuraman, A., Zeithaml, V. A., \& Berry, L. L. (1988). SERVQUAL: A Multiple-Item Scale For Measuring Consumer Perceptions of Service Quality. Journal of Retailing, 64, 12-40.

Peter, P. J., \& Olson, J. C. (2010). Consumer Behavior and Marketing Strategy. McGraw-Hill Irwin.

Polasik, M., \& Wisniewski T. P. (2008). Empirical Analysis of Internet Banking Adoption in Poland. International Journal of Bank Marketing, 27, 32-52. https://doi.org/10.1108/02652320910928227

Poon, W. C. (2008). Users' Adoption of E-Banking Services: The Malaysian Perspective. Journal of Business \& Industrial Marketing, 23, 59-69. 
https://doi.org/10.1108/08858620810841498

PwC (2019). Thống kê toàn câuu năm 2019: It’s Time for a Consumer-Centred Metric: Introducing 'Return on Experience'.

https://www.pwc.com/gx/en/consumer-markets/consumer-insights-survey/2019/report.pdf

Reinartz, W. J., \& Kumar, V. (2000). On the Profitability of Long-Life Customers in a Noncontractual Setting: An Empirical Investigation and Implications for Marketing. Journal of Marketing, 64, 17-35. https://doi.org/10.1509/jmkg.64.4.17.18077

Santos, J. (2003). E-Service Quality: A Model of Virtual Service Quality Dimensions. Managing Service Quality: An International Journal, 13, 233-246.

https://doi.org/10.1108/09604520310476490

Sathye, M. (1999). Adoption of Internet Baking by Australian Consumers: An Empirical Investigation. International Journal of Bank Marketing, 17, 324-334. https://doi.org/10.1108/02652329910305689

Sein, M., \& Chey, C. K. (2013). Demographic Factors in the Evaluation of Service Quality in Higher Education: A Structural Equation Model (SEM) Approach. International Journal of Marketing Studies, 6, 90-102.

Shin, H. P. (2008). Continued Use of a Chinese Online Portal: An Empirical Study. Behaviour \& Information Technology, 27, 201-209. https://doi.org/10.1080/01449290600802403

Spacey, R. et al. (2004). The Power of Influence: What Affects Public Library Staff's Attitudes to the Internet? Library Management, 25, 270-276. https://doi.org/10.1108/01435120410547922

Supinah, R., Anis, Z., \& Amin, H. (2008). Banking Channels Adoption in Malaysia: An Analysis Rostinah Supinaha. Labuan e-Journal of Muamalat and Society, 2, $17-26$.

Times, S. (1996). Finding out Who Surfs the Internet Is Their Business.

Tolpa, E. (2012). Measuring Customer Expectations of Service Quality: Case Airline Industry. Master's Thesis, Aalto University.

Tran, D. T. (2015). Research on the Relationship among E-Banking Service Quality, Customer Satisfaction and Customer Loyalty in Vietnam. Ph.D. Thesis, National Economics University.

Tran, P. H. (2018). Factors Affecting Service Quality in Vietnamese Retail Banks. Journal of Banks and Bank Systems, 13, 39-48. https://doi.org/10.21511/bbs.13(2).2018.04

Van, D., \& Lee, P. (2012). Examining Service Quality and Customer Satisfaction in the Retail Banking Sector in Vietnam. Journal of Relationship Marketing, 11, 199-214. https://doi.org/10.1080/15332667.2012.741022

Wang, M. (2003). Assessment of E-Service Quality via E-Satisfaction in E-Commerce Globalization. The Electronic Journal of Information System in Developing Countries (EJISDC), 11, 1-4. https://doi.org/10.1002/j.1681-4835.2003.tb00073.x

Yoo, B., \& Donthu, N. (2001). Developing a Scale to Measure the Perceived Quality of an Internet Shopping Site (SITEQUAL). Quarterly Journal of Electronic Commerce, 2, 31-47.

Zeithaml, V. A. (1988). Consumer Perception of Price, Quality and Value: A Means end Model and Synthesis of Evidence. Journal of Marketing, 52, 2-22. https://doi.org/10.1177/002224298805200302

Zeithaml, V. A., \& Bitner, M. J. (2000). Services Marketing: Integrating Customer Focus across the Firm (2nd ed.). McGraw-Hill.

Zeithaml, V. A., Berry, L. L., \& Parasuraman, A. (1996). The Behavioral Consequences of Service Quality. Journal of Marketing, 60, 31-46.

https://doi.org/10.1177/002224299606000203 